\title{
Research on the Teaching Reform of the Course of High Voltage Technology Based on the Mixed Teaching Mode
}

\author{
Li Jin, Du Yanhong, Wu Haiyun, Sun Qiang, Gao Jihui \\ College of Engineering and Technology \\ Tianjin Agricultural University \\ Tianjin, China \\ Davidjin2013@163.com
}

\begin{abstract}
High voltage technology is an important professional course of electrical engineering and automation, and with the rapid development of new technology, it is necessary to explore the teaching reform of high voltage technology. According to the characteristics of undergraduate teaching, to broaden their knowledge and cultivate talents for the purpose, from the characteristics of the course, teaching content, teaching methods and means of experiment and practice teaching reform in the course of exploration, at the same time mixed teaching model as the starting point, from the multimedia teaching and the traditional teaching mode, mixed multimedia teaching and teaching video mixed mode, online and offline teaching mixed mode, multimedia teaching and laboratory teaching mixed mode, discusses the mixed teaching mode in "high voltage technology" Curriculum Teaching in the application of the feasibility and superiority, and how to better mixed teaching mode applied to the "high voltage technology" the course of teaching
\end{abstract}

Keywords-blended teaching; Information teaching; High voltage technology; Reform in Education

With the rapid development of information technology education in Colleges and universities, or digital network teaching with its rich resources, intuitive interface, convenient and wide influence the characteristics of affects the college students' learning and thinking ${ }^{[1]}$, but also greatly affect the teacher's teaching methods, teaching contents and teaching methods. How to make full use of information technology in teaching initiative, give full play to the guiding role of teachers and inspire the learning of the students, as hybrid teaching mode, quietly changing the traditional teaching mode in universities.

\section{AN OVERVIEW OF BLENDED TEACHING MODEL}

The mixed teaching mode combines the advantages of traditional teaching with the advantages of modern information technology and information network teaching, and thus realizes the complementary advantages of both geology and information technology ${ }^{[2,3]}$. In the teaching process, according to the characteristics of teaching content, teaching target and the teaching object, the teaching design, reasonable selection and use of modern teaching media, and combining it with traditional teaching methods, to participate in the whole teaching process, the effect of many kinds of media information to the students to form the structure of reasonable teaching process, to achieve the best teaching effect.

We present application of the mixed mode teaching contains mixed, with the line on the line of traditional teaching and modern information technology teaching under the mixed learning objectives, blended learning resources, learning style and mixed. The core idea is according to the requirements of different teaching contents, teaching, using different ways to solve the ${ }^{[4-6]}$ in teaching is to solve the problem by using different media and information transmission mode, and the way to solve the problem of learning to benefit maximization, cost minimization of time and energy. Its intent is shown in Fig.1.

Innovation and Entrepreneurship Training Reform Model Projects of Tianjin Agricultural University (20170102) 


\begin{tabular}{|c|c|c|c|}
\hline & $\begin{array}{l}\text { Basic knowledge } \\
\text { learning }\end{array}$ & $\begin{array}{c}\text { Knowledge } \\
\text { expansion stage }\end{array}$ & $\begin{array}{c}\text { Practical } \\
\text { application phase }\end{array}$ \\
\hline $\begin{array}{l}\text { Capability } \\
\text { requirement }\end{array}$ & Primary skills & Higher-order thinking & Advanced skills \\
\hline \multirow[t]{2}{*}{$\begin{array}{l}\text { Learning } \\
\text { content }\end{array}$} & $\begin{array}{l}\text { Gases, liquids and Solid } \\
\text { electrical strength }\end{array}$ & $\begin{array}{l}\text { Actual electrical } \\
\text { strength }\end{array}$ & Curriculum design \\
\hline & \begin{tabular}{l}
\multicolumn{2}{c}{ Three stage teaching } \\
(prep+
\end{tabular} & Case teaching & $\begin{array}{l}\text { One stage teaching } \\
\text { (Discussion) }\end{array}$ \\
\hline $\begin{array}{c}\text { Educational } \\
\text { theory guidance }\end{array}$ & $\begin{array}{l}\text { Cognitive learning } \\
\text { theory }\end{array}$ & $\begin{array}{l}\text { Cognitive learning theory }+ \\
\text { Constructivism theory }\end{array}$ & Constructivism theory \\
\hline $\begin{array}{l}\text { learning } \\
\text { environment }\end{array}$ & $\begin{array}{c}\text { Classroom }+ \text { Teaching } \\
\text { website }\end{array}$ & $\begin{array}{c}\text { Classroom }+ \text { Teaching } \\
\text { website }\end{array}$ & Teaching website \\
\hline $\begin{array}{c}\text { Classroom } \\
\text { teaching method }\end{array}$ & Personal & $\begin{array}{l}\text { Personal + Group } \\
\quad \text { discussion }\end{array}$ & Group cooperation \\
\hline $\begin{array}{l}\text { Students cognition } \\
\text { process }\end{array}$ & $\begin{array}{l}\text { Stages of learning and } \\
\text { imitation }\end{array}$ & $\begin{array}{c}\text { Stages of learning } \\
\text { Stage and design stage }\end{array}$ & Design and innovation \\
\hline Teacher time & More & Much more & Less \\
\hline
\end{tabular}

Fig. 1 Schematic diagram of mixed teaching mode

\section{High Voltage Technology Course Features}

High voltage technology is a major course in electrical engineering and automation. The total hours of the course for 48 week for 4 , how to get the best teaching effect in the limited hours, to enable students to better grasp the course content, and to maximize the cultivation of students' engineering practice ability and innovation ability, enhance students' interest in learning, is an urgent need to solve the problem. According to the teaching experience of the teaching and research group in recent years, the author explores the teaching reform of the course from the aspects of the characteristics of the course, the teaching content, the teaching methods and means, and the experimental practice.

In the course of university physics, circuit analysis, power system analysis and electromagnetic field course based on the background, research in high voltage and high magnetic field, high voltage insulation and overvoltage protection of experiment. Students through the course of study, can systematically grasp the basic characteristics of the insulation of electrical equipment, mastering the mechanism and protective measures of overvoltage and lightning overvoltage in electric power system, the basic theory of internal wave process, correctly understand the basic concepts of power system insulation coordination, grasp the principle and method of power equipment insulation test that can solve the actual problem of high voltage technology.

The course of high voltage technology involves a wide range of knowledge integration, high concentration of the essence of the professional knowledge, in the professional curriculum system has a connecting link between the preceding and the following role. This course is difficult to teach, take more hours, and students understand it is also more difficult. In the lecture, it is necessary to integrate the basic content of the course to the students to learn the knowledge, through this course organically and harmoniously together.

The course content of high voltage technology is large and the number of hours is 48 . It is very important to ensure the quality of teaching in a limited number of hours. The teaching of this course can be based on the teaching contents will be combined with the current status of the development of electric power industry and other aspects of analysis and research, carefully select the teaching content, teaching methods and reasonable arrangements for the order. After the selection of the teaching content, focusing on the cultivation of students' engineering application ability, and then according to the characteristics of the various sections of the course to take different forms of teaching and order, in order to develop the quality and ability of students. The main content of the course of high voltage technology is divided into three parts. This paper mainly describes the discharge mechanism and law of the gas, liquid and solid dielectrics, the insulation characteristics under high voltage, the insulation method and the surface discharge. The basic characteristics and breakdown mechanism which should focus on gas insulation breakdown, in teaching mechanism of gaseous dielectric this part, mainly should be two theories seize large 
PD and PD is less gas breakdown, and the basic characteristics of teaching in gas insulation breakdown, starting from several main factors, focusing on effect of electric field on the uniformity of air breakdown voltage, so that students be clear, clear concept. While the knowledge of the discharge mechanism and surface discharge of liquid and solid dielectrics is emphasized, the breakdown of these cases and the different characteristics of breakdown in gas medium are emphasized.

The second part of the high voltage technology course is the insulation test. Mainly about electrical equipment insulation characteristics of various testing methods, including basic principle, test equipment, test wiring and experimental test method; AC/DC high voltage and high voltage shock generation methods, basic principle, measuring method and device. Because of this part of the project has a strong practical, so in the teaching of these contents, classroom teaching focuses on the basic principles and methods of teaching on the ${ }^{[7,8]}$.

The third part of the high voltage technology course is the overvoltage and insulation coordination of power system. The main contents include transmission line and winding wave process, lightning overvoltage and the generation of internal overvoltage, the basic characteristics and protection measures, protection methods, etc. In this part, we focus on the theoretical teaching, especially in the teaching of the transmission line and the winding process. As part of the content of this course is a difficult and important, it is the basis for the analysis of over-voltage, so the teaching hours more arrangements to explain thoroughly. In the overvoltage part explains formation mechanism and basic characteristics of voltage, and on the part of the protection methods and protective measures are introduced briefly, after the end of the course to the electricity sector production practice, please in front of full-time engineers practicality teaching, so that students can personally experience and feel the importance of voltage protection and related measures, and make the students have a new understanding of high voltage technology status and development, broaden their horizons, but also to mobilize their enthusiasm for learning.

\section{Mixed Mode Teaching of High Voltage Technology}

High voltage technology developed very rapidly, the latest research results continue to emerge, teaching must also keep pace with technology development, combined with the existing teaching content will be introduced to expand the application field gradually mature, and the new technology to the students. In the explanation of corona discharge, in addition to explaining the current $500 \mathrm{kV}$ voltage level of corona protection measures, combined with China's development of UHV and EHV transmission line to the $1000 \mathrm{kV}$ line, Japan's Tokyo electric power company, the 8 section $810 \mathrm{~mm}^{2}$ wires split spacing is $40 \mathrm{~cm} 8$ bundle conductors can be reduced to the noise, corona $500 \mathrm{kV}$ line level $(50 \mathrm{~dB})$ as an example, the importance of the UHV corona limit problem.

Make full use of multimedia teaching means, open a new vision, based on the teaching mode of multimedia teaching and traditional mixed, mixed mode focusing on online and offline, complementary advantages of online teaching and classroom teaching to improve the students' cognition, master, digestion effect. The line refers to the current classroom teaching, we make full use of multimedia teaching, the multimedia teaching of each class down more teaching content, abundant data, information, knowledge, students' understanding, digestion and absorption, the notes are needed to strengthen the classroom under review, two study. As a result, online teaching highlights its importance ${ }^{[9]}$. Online teaching is to make full use of digital campus network, each class teacher the teaching content, teaching focus and teaching courseware, homework, review questions, learning points and related information upload to campus LAN, students can download all after-school through online courseware information, further digestion and absorption, improve their own classroom learning. At the same time, teachers can communicate with students through online communication, discussion and other ways to help students achieve the purpose of classroom teaching.

Add the appropriate teaching video, image based on mixed mode of multimedia teaching and traditional teaching on the teaching mode, that makes more sense in the high voltage technology teaching, are of great help to the teaching, can make full use of. For example, the method can produce the principle of AC / DC high voltage and high voltage impact production as a targeted teaching video or image projected by 3-5 minutes, it's full of picture and sound to let students eyes break the physical constraints, multi angle mobilize the interest of students, students can directly see a lot of discharge the phenomenon of related teaching contents in the classroom could not see the effect than the language expression in place, wonderful, easy to accept, more conducive to the students to understand and master.

In order to promote students' positive thinking, cultivate students' autonomous learning ability, and stimulate students' interest in learning, we should use advanced teaching methods and means to effectively mobilize students' learning enthusiasm. In teaching, we mainly adopt the following teaching methods and means:

At the same time, we should pay attention to improve the students' interest in learning, give play to the initiative of learning, pay attention to guide students' thinking, cultivate students' independent thinking ability and creative thinking ability. From the beginning of the first class, through a large number of pictures, demonstrates the development and application of high voltage technology, including the power industry, nuclear technology, environmental protection, etc.. Through these vivid examples to enable students to understand the high voltage technology in fact around. The content of this course is not only a strong theoretical, but also a practical combination of engineering and technology courses. In explaining the restrictions of corona discharge, corona discharge in order to explain several restrictions, first given empirical formula of high-voltage conductor surface field strength and voltage, and then guide the students to understand themselves in accordance with the formula, say the restrictions, and analyze what restriction measures play a major role. In this way, students not only learn the knowledge, but also learn how to analyze and solve the problems in the 
field of high voltage. These measures have changed the passive acceptance of students in the past, the students' interest in this course has greatly increased, learning initiative.

The combination of multimedia teaching and blackboard teaching. For some important formula derivation and the principle of content such as the use of blackboard writing teaching, in order to strengthen the memory of students. But for a large number of the circuit or wiring diagram, physical equipment and internal structure and photo voltage waveform of high voltage technology courses, if drawing on a blackboard to spend more time and the effect is not good, then the use of multimedia teaching, not only increase the amount of information in teaching, and the emphasis and difficulty of illustrations and courses can be repeated advice and review, easy to understand and grasp the course content, the teaching of intuition, and achieved good results. In the teaching process, the Matlab simulation software and high voltage technology organically, which not only reduces the abstraction of some content in the curriculum, enhance the visibility, and let the students in the classroom can easily learn to use the most advanced programming tool. The relatively easy to use software Matlab/Simulink SimPowerSystem toolkit, including a variety of devices, power supply, transformer, reactance and capacitance and oscilloscope measurement and waveform display element, can some circuit structures in the textbooks, the output of the simulation results, shown to the students in the classroom play; also can easily modify the parameters of the circuit, for some problem analysis.

\section{Strengthen the EXPERIMENT AND PRACTICE}

\section{A. Strengthening experimental teaching}

The training of high voltage test ability is an important part of learning and mastering high voltage technology. For a limited number of hours, the quality of the experimental class, to do the following two aspects:

(1) Clear teaching experiment two main tasks, one is the theoretical knowledge learned in the course to consolidate and deepen the understanding of the two is to learn the actual test skills, including learning instruments commonly used test methods, commonly used in practical engineering and equipment based on the operation method, and through experiment. The training of the ability and the good habits for the future, engaged in a variety of practical experiment foundation for certain. Both of which can be neglected.

(2) Clarify the importance of the experimental report. The experiment report is not "current account", should not be simply to set up the experimental data with professional knowledge, should try to exercise their own on the basis of the study, the ability of the experimental data, a comprehensive analysis of the results for the conclusion. The experiment report should reflect the real situation of the experiment, including the experimental content, experimental circuit, experimental data and experimental phenomena. The data in the experiment report, including the data in the chart, should be clearly stated.

\section{B. Strengthen the cultivation of practice and innovation ability}

In order to further develop the students' practical and innovative ability, we also set up a number of comprehensive and design oriented experiments. One of the latest technologies such as the field of high voltage dielectric barrier discharge experiment, the content does not appear in the classroom, we allow students to find relevant literature, understand the principle and way of design, experimental program written by the students themselves, experimental procedures, and then to the laboratory practice, in this way the culture ability students in many aspects. After the reform of the experimental setup, the students have a strong interest in experiment, and some students are required to do some more difficult experiments. In addition to the election to do the experiment, but also in the graduation design of the high voltage technology related topics. In order to further improve the teaching effect of the course, the students who have the ability to learn, but also to guide them to participate in the project practice of college students, and give appropriate funding and guidance. In order to adapt to the need of the training of the compound talents of electrical engineering in the new century, combining with the practical teaching base, strengthening the practice teaching. Before studying this course, students use the opportunity to practice the power plant, substation and power operation Department studying for three weeks, to fully understand the process of power generation, transmission, substation and distribution, especially the operation mode, high voltage power equipment experimental principle and physical etc.. Let the students into the classroom with problems, improve the initiative of learning. After the end of the course, students will use the opportunity of graduation practice to the power plant and substation for two weeks of graduation practice, let the students into the field of practice theory.

\section{CONCLUding REMARKS}

Application of Hybrid Teaching Mode in "high voltage technology" course teaching has been implemented in the Tianjin Agricultural University and received good results, suggestions for the multimedia teaching and the traditional teaching mode, multimedia teaching and teaching hybrid film mixed mode, online and offline mixed mode, multimedia teaching and laboratory teaching in high mixed mode voltage technology in the teaching of promotion.

\section{ACKNOWLEDGMENT}

This work was financially supported by the Innovation and Entrepreneurship Training Reform Model Projects of Tianjin Agricultural University (20170102).

\section{REFERENCE}

[1] Fupeng Tian etc. The practice and exploration of the blended teaching mode in Colleges and Universities under the information environment [J]. E-education Research,2015(04)

[2] Shujun Zhang etc. The development of network course and mixed teaching mode [J]. Higher Education of Sciences, 2011(03)

[3] Gaoxiang Li etc. On the necessity and reality of the mixed teaching mode [J]. Modern Distance Education Research,2014(01) 
[4] Weimin Sun etc. On the teaching design and implementation in multimedia teaching environment $[\mathrm{J}]$. Journal of Jiaxing University,2012(S1)

[5] Jie Li etc. Application of multimedia teaching in teaching reform [J]. Science and technology in Western China,2014(27)

[6] Rong Xu. The application of multimedia teaching in the reform of colleges and Universities [J]. Journal of kaifeng institute of education,2016(04)
[7] Guangshun Hu etc. Advantages and disadvantages of multimedia teaching and Countermeasures $[\mathrm{J}]$. China Science and technology information,2015(13)

[8] Zhijuan Tang etc. Practice and thinking of multimedia teaching mode [J]. China Science and technology innovation,2016(10)

[9] Hao Song etc. Some thoughts on laboratory teaching in Colleges and Universities [J]. Technology consulting,2015(15) 